15. ラット顎切蒾萌出に伴う，歯周組織の改造に関する 基礎的研究 (1)

\author{
豊島 雅子・山本 博武 \\ (九歯大 $\cdot 2$ 保存)
}

艟島 邦昭・鸤村 昭辰 (九歯大 2 口解)

近年, 近年, 線維芽細胞は, コラーゲンの合成ならび に分泌のみならず，膠原線維の吸収，分解の機能をも有 し, 結合組織の改造に対する積極的な関与が示唆されて いる、今回我々は, 無根雬であるため一生を通じて萌出 しつづけるラット划蒾の莯周組織の改造, 特に線維芽䊼 胞の動態について観祭を行った。

実験には30匹しラットの下顎存側切岿を用いた。㐘牙 の萌出を促進するため 2 日毎に 2 週間にわたって付側切

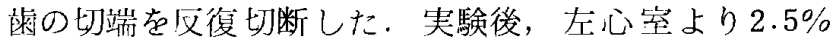
glutaraldehyde で灌流固定し，その後冷公中で10\% EDT A- 2 Naで脱㕄. $1 \% \mathrm{OsO}_{4}$ で 2 時間後固定後通法 に從って, Epon 812 に包埋し, 白状面の切! 个調整を行 い舌側雨肉組織を钼察した。一部の脱灰標本は訟性つォ スファターゼの電顕的検出のため, Vibratomeで $40 \mu \mathrm{m}$ の切片を作製し, Gomori 液 $(\mathrm{pH} 5.0)$ で $37^{\circ} \mathrm{C}$ で 30 分閒 反応を行い， $1 \% \mathrm{OsO}_{4}$ で後固定した後, 通法に彷って 切版調製し，透過電頙で観祭した。さらに試料の一部は 凍結切片とし, 浸漬液にて反灾後光光顕に供した. その 結果，次の様なことが钼察された。接合上皮直下で歯牙 に接した歯周組織 (Tooth-related part)には紲胞の 変性, 崩壊がみられたこの部位の線維弐細胞は, 酸性フ オスファターゼ活性を示す水解小体を多数有していた。 これらの線維讶細胞質内には貧食された膠原線維が多数 観察された，又酸性フォスファターゼの活性はその他の 結合組織細胞内にも観祭された。この様な細胞の周囲で

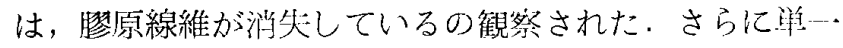
線毛を有する線維芽細胞がしばしば見られ，问絬胞が咸 囲の膠原線維支貪食するために積極的に機能しているこ とが推測された。

\section{6 下顎大臼歯の曲徵と幅厚示数との相関について}

$\begin{array}{cl}\text { ○伊東 } & \text { 励・村上 守良・六反田 篤 } \\ \text { 山田 博 } & \text { 九歯大・1口解) }\end{array}$

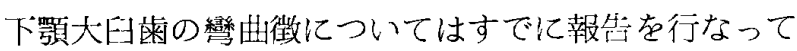
いるすなわち米冠各部抽よび咬合面観の輪郭で近心煩 側の彎曲度を近心角, 遠心煩側の彎曲度を遠心角とし，
近心角と遠心角との差を彎曲徽をなす角度とするととに

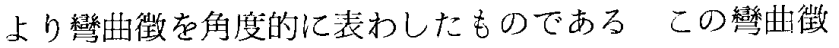
が下顎大曰雨において棶冠幅早示数とどのような成係に あるのかを知るため，稚曲徽と幅愿示数との相関性につ いて検討した。

調査材料は“下顎不側の大曰㐘で5咬頭のもののうち， 咬合面溝の形態により, 第 1 大歯は $Y_{5}$ 型10歯, $+_{5}$ 型10 歯, $\mathrm{X}_{5}$ 型10歯, 第 2 大F蒾では+ 5 型10歯, $\mathrm{X}_{5}$ 型10䊝の 計50雪であり，歯頸部，歯冠中央部，咬合盲より米冠 6 分の1の部および咬合面観の各輪郭について行なった。 その結果は次のでとくである。

1. 㕮合面瑇の形態から第 1 大曰雪ではX型が+型, $\mathrm{Y}$ 型より負の相関関係が搔く，第 2 大印米でも $\mathrm{X}$ 型が゙ 型より負の相関関係加溞い傾问を示した。

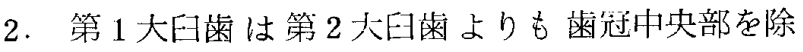
き, 咬合面観輪郭および他の輸郭において負の相関関係 が溞い傾向を示した。

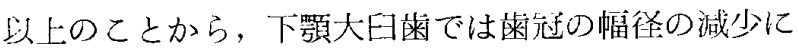
ともない彎曲徵は䁌加する傾向を赤す．この傾向は咬合 面淮の形態ではX型が+型より強く，また第 1 大曰柬は 第 2 大䍝蒾より強く表わすものと思われる。

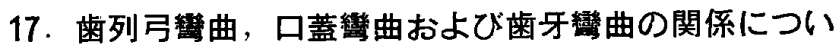 乙 一第 2 報一}

○高木 明夫・豊田 静夫 (九歯大 $\cdot 1$ 補)

天然歯列を有する成人についてその朄列形態，個々の 蒾牙の植立状態および䫚の形態的特徽を知っておくとと は歯科臨休を行うにあたって重要であると思われる。そ こで今回は日蓋形態と雪列形態について計澌を行った。

被験者は上下顎とも健全な天然歯列を有するか，修得 物が歯牙や蒾列の形態を椇わないようなもので, 翼歯以 外の众損，著明な口蓋隆起およびび矯正の覞往がないも のとし，19歳から 29 瓷までの罗子43名, 女子 10 名とし t.

口蓋の計澌は，口莣面に設けた原点を通って前頭面に 平行にトレースして得た断面図を用いて，第1報におい て発表した口蓋形態示数，口蓋幅品示数，口蓋傾斜度を 計り，合わせて非態を視覚的に分類した。

柬列の計澌は，原点を中心として歯牙の备部の坐係を 3 次元座標澌定機で計測し，それを方腿紙上にプロット して行った。計澌は口蓋の計测と同しように行い，雪列 形態示数および閧開角を計った。 
口蓋の断面図から门蓋形態を方型 $(41.5 \%) ，$ 型 $(47.2 \%) ， \mathrm{~V}$ 字型 $(11.3 \%)$ 亿分類した。蓋形態を 示数, 傾斜度によって分けると, 方型は示数 1.70 以上, 傾斜度 $50^{\circ}$ 以上，円型は $1.45 \sim 1.75$ 己 $48^{\circ} \sim 55^{\circ}$, V字型 は1.50以下.52以下という範囲で备型が分けられそうで ある・

歯列の形態は視覚的に放物線型, 円型, 黄门方型, 方 型，V字型の 5 型に分類した。それぞれの出現率は 45.3 $\%, 28.3 \%, 13.2 \%, 7.5 \%, 5.7 \%$ で他の研究者々同㥞 の数值を示した。坐㯲を用いた歯列の計澌で歯列形態示 数之展開角の間に負の相関があり，雬列形態示数と口蓋 形態示数との有意の相関はなかった，柬列と口蓋形態の 視覚的分類において V等型の歯列には口蓋形態はV字型 のみ，放物線型には方型，円型には円型の山蓋形態が多 く，带垖型と方型にはV字型はなかった。

\section{8. 総義歯人口歯咬合面形態の経時的変化に関する研究 (第 1 報〉}

○清水 稔弘・三宅 茂樹・豊田 静夫 (九蒌大・ 1 補)

機能的に製作した義雪も使用期間が言くなると，人工 菌の摩耗が進んでくる そこで義歯装着時における人て 柬の咬合の観察, 調整期間がどのくらい必要か，またど の上うに咬合小面が形成，あるいは摩耗していくか上い うことについての示唆を得る目的で，まず咬合平面への 咬合小面投影面積の変化を経時的に観察した。

面積測定には紙片重量測定法を利用し，定型試験片を $10^{\circ}, 20^{\circ}, 30^{\circ}$ 乙傾斜させ，その形態を万能投影機で 10 倍抎大し，その理論值と测䇥值とを比較したところ Beckman社製チャート紙の $1 \mathrm{~mm}^{2}$ 当りの重量は $5.15 \times$ $10^{-3} \mathrm{~g}$ であり, 愦养率は $0.3 \%$ で定定していて本湖究に 利用できると判定した 被験者は曰歯部にユニルックス

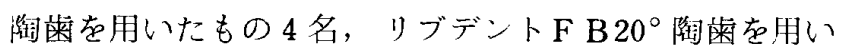
たもの 1 名を対象とし，通法により上下総義雪を製作 し, 装着時より 1 力月每に 6 力月（1例のみ 7 力月）後 まで義雪を印象し，その莫型を計測した。測定部位は阴 嚼機能に最も関係が哚い左右側臼歯部の前方咬合小面と した，慔型基底面を咬合平面に平行になるように調製 し，咬合小面存記入後，万能投影機で抬大トレースし たこれを切り取り、メトラー直視天科により重量を測 定し，面積を算出した

結杲は以下のと抢りである。
1. ほとんどの弪例で摩耗は義菌装着直後より急激に 起こり，3〜4 カ月で少し落ちつきを示した。

2. 一䫑では舌側咬頭部より煩側咬頭部の方が藏い摩 耗率を泳し，上顎では逆の傾向を示した。

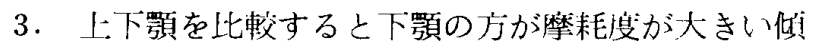
向にあった。

4. 自動削合後において認められなかった收合小面が $1 \sim 2$ 力月後に現われてきた。

\section{9. 総義四床座面積について（第 2 報）}

\section{○古橋 会治・三宅 茂樹・脰田 静夫 \\ (九柬大 $\cdot 1$ 補)}

総義崡林坐組織の大きさは，義菌の維持力，安定性， 咬合力，咀嚼能率等に影響を及ぼすと言われており，ま た，顎堤の形態は側方分力に対する抵抗力扔よび咬合力 に影響するこ言われている。

前回は，第 1 報として総義雪休座面積をメッキ法によ り測定する方法について述べたが，今国は投影面積の測 定法と测定結果，および顎堤の形態を高さと広さにより 分析した。

被験者は上下無歯顎患者で影形態が正常で，機能に異 常がなく，義崡装着後の維持安定が良好なもの46名を対 象とした。

通法に従って印象採得，咬合採得を行い，坪根式顔恧 京使用して，咬合斗面が基準平面しなるように慔型を坢 根式MS型咬合器に付着した．との上下顎模型に外形線 を描記して咬合平面に対して垂值方向から $105 \mathrm{~mm} レ ン$ ズを使用してスケールとともに撮影し， $1 \mathrm{~mm}$ 方眼紙上: へ抬大トレースを行い，マス目読み取り法により面積を 求切。

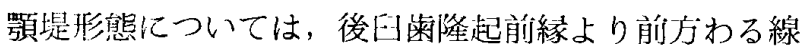
$15 \mathrm{~mm}$ の点（第 1 大四歯相当部）で歯槽頂線と垂直に交 が煩側床緣, 柬槽頂線, 舌側休縁と父わる点を描記し, 三次元読み取り顕微鏡により三点の座穄を求加て柬槽頂 線から各々の点までの垂直距離を高さとし, 水平距離を 広さとした。

床座組織の投影面積の平均值と檪準偏差は，上䫟て

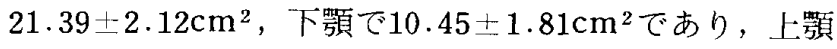
対下顎の比は約 2:1 であった。下顎第 1 大四菌相当 部顎堤の高さについては，左右之も煩側が舌側よりも $1 \mathrm{~mm}$ 高く, また, 右側が左側より約 $1 \mathrm{~mm}$ 高かった。

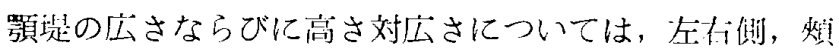

